\title{
INVESTIGATION OF WEAR BEHAVIOR OF BORIDED AISI D6 STEEL
}

\author{
PREISKAVA OBRABE BORIRANEGA JEKLA AISI D6
}

\author{
Ibrahim Gunes ${ }^{1}$, Salih Kanat ${ }^{2}$ \\ ${ }^{1}$ Afyon Kocatepe University, Faculty of Technology, Department of Metallurgical and Materials Engineering, 03200 Afyonkarahisar, Turkey \\ ${ }^{2}$ Afyon Kocatepe University, Institute of Natural and Applied Sciences, Department of Metallurgical and Materials Engineering, \\ 03200 Afyonkarahisar, Turkey \\ igunes@aku.edu.tr \\ Prejem rokopisa - received: 2014-11-09; sprejem za objavo - accepted for publication: 2015-07-02
}

doi:10.17222/mit.2014.279

\begin{abstract}
We have investigated the effect of the boriding process on the wear behavior of AISI D6 steel. The boride layer was characterized by light microscopy, X-ray diffraction and micro-Vickers hardness testing. The X-ray diffraction analysis of the boride layers on the surface of the steels revealed the existence of the $\mathrm{FeB}, \mathrm{Fe}_{2} \mathrm{~B}, \mathrm{CrB}$ and $\mathrm{Cr}_{2} \mathrm{~B}$ compounds. Depending on the chemical composition of the substrates, the boride-layer thickness on the surface of the AISI D6 steel was found to be 164.42 $\mu \mathrm{m}$. The hardness of the boride compounds formed on the surface of the steels ranged from $1672 \mathrm{HV}_{0.05}$ to $2118 \mathrm{HV}_{0.05}$, whereas the Vickers hardness value of the untreated steels was $584 \mathrm{HV}_{0.05}$. The wear tests were carried out using a ball-disc arrangement under dry-friction conditions at room temperature with an applied load of $10 \mathrm{~N}$ and a sliding speed of $0.3 \mathrm{~m} / \mathrm{s}$ for a sliding distance of $1000 \mathrm{~m}$. It was observed that the wear rate of the borided and unborided AISI D6 steel ranged from $1.28 \times 10^{-6}$ to $81.2 \times 10^{-6} \mathrm{~mm}^{3} / \mathrm{Nm}$

Keywords: AISI D6, boriding, micro-hardness, friction coefficient, wear rate
\end{abstract}

V študiji je bil preiskovan vpliv postopka boriranja na obrabo jekla AISI D6. Borirana plast je bila pregledana s svetlobno mikroskopijo, $\mathrm{z}$ rentgensko difrakcijo in izmerjena je bila mikrotrdota po Vickersu. Rentgenska difrakcijska analiza borirane plasti je pokazala prisotnost spojin $\mathrm{FeB}, \mathrm{Fe}_{2} \mathrm{~B}, \mathrm{CrB}$ in $\mathrm{Cr}_{2} \mathrm{~B}$. Odvisno od kemijske sestave podlage je bila debelina borirane plasti na jeklu AISI D6 164,42 $\mu$ m. Trdota boridov, nastalih na površini jekla, je bila med $1672 \mathrm{HV}_{0,05}$ do $2118 \mathrm{HV}_{0,05}$, pri čemer je bila trdota neobdelanega jekla po Vickersu $584 \mathrm{HV}_{0,05}$. Preizkusi obrabe so bili izvedeni na sestavu kroglica-plošča, pri pogojih suhega trenja pri sobni temperaturi, z uporabljeno obremenitvijo $10 \mathrm{~N}$, s hitrostjo drsenja $0,3 \mathrm{~m} / \mathrm{s}$ in potjo drsenja 1000 $\mathrm{m}$. Ugotovljeno je, da je hitrost obrabe boriranega in neboriranega jekla AISI D6 v območju od $1,28 \times 10^{-6}$ do $81,2 \times 10^{-6}$ $\mathrm{mm}^{3} / \mathrm{Nm}$.

Ključne besede: AISI D6, boriranje, mikrotrdota, koeficient trenja, hitrost obrabe

\section{INTRODUCTION}

Boriding is a thermochemical surface-hardening process that occurs with the diffusion of boron atoms into a variety of metals; including ferrous, non-ferrous and some superalloy surfaces between $973 \mathrm{~K}$ and $1373 \mathrm{~K}$ for a period of time ranging from $0.5 \mathrm{~h}$ to $12 \mathrm{~h}$. Boriding can be performed in numerous ways, including plasma, paste, gas, molten salt, electrolysis, and pack boriding. Depending on the boriding parameters and the chemical composition of the substrate, the diffusion of boron atoms into their substrates leads to the formation of iron and metallic borides. The produced layers provide an extremely high hardness, good tribological properties and anti-corrosion resistance of the treated surfaces. ${ }^{1-10}$

One of the most important reasons for machine parts to suffer damage and fail is wear. The surfaces of tool steel, dies and the majority of the machine parts (pumps, crankshafts, rolls and heavy gears, motor and car construction) are commonly subjected to higher stresses, wear and corrosive damage. In these types of working conditions, surface properties are often the most important for a reliable and long economic service life. In order to reduce this loss, the properties of the surfaces should be improved. The diffusion of boron atoms into the surface of the materials is a common boriding treatment to improve the surface properties of industrial mechanical parts and tools. Among these surface-hardening treatments, boriding is a highly effective method for increasing the surface hardness, wear resistance, corrosion resistance and high-temperature oxidation resistance. ${ }^{11-13}$

The wear behavior of borided steels has been evaluated by a number of investigators. ${ }^{14-19}$ However, there is no information about the friction and wear behaviors of borided AISI D6 steel. The main objective of this study was to investigate the effect of the boriding process on the wear behavior of borided D6 steel. The structural and tribological properties were investigated using light microscopy, XRD, SEM, EDS, microhardness tests and a ball-on-disc tribotester.

\section{EXPERIMENTAL PROCEDURES}

\subsection{Boriding and characterization}

The AISI D6 steel contained $2.08 \%$ of mass fractions of $\mathrm{C}, 12.3 \%$ of mass fractions of $\mathrm{Cr}, 0.6 \%$ of mass 
fractions of $\mathrm{W}, 0.16 \%$ of mass fractions of $\mathrm{Ni}, 0.36 \%$ of mass fractions of $\mathrm{Mn}$ and $0.25 \%$ of mass fractions of $\mathrm{Si}$. The test specimens were cut into $\varnothing 28 \times 10 \mathrm{~mm}$ dimensions, ground up to $1200 \mathrm{G}$ and polished using a diamond solution. The boriding heat treatment was carried out in a solid medium containing an Ekabor-II powder mixture placed in an electrical resistance furnace operated at $1123 \mathrm{~K}$ and $1323 \mathrm{~K}$ for 2 and $8 \mathrm{~h}$ under atmospheric pressure. The microstructures of the polished and etched cross-sections of the specimens were observed under a Nikon MA100 light microscope. The presence of borides formed in the coating layer was confirmed by means of X-ray diffraction equipment (Shimadzu XRD $6000)$ using $\mathrm{Cu}-K_{\alpha}$ radiation. The hardness measurements of the boride layer on each steel and untreated steel substrate were made on cross-sections using a Shimadzu HMV-2 Vickers indenter with a $50 \mathrm{~g}$ load.

\subsection{Friction and wear}

To perform the friction and wear of borided samples, a ball-on-disc test (ASTM G99-05) device was used. ${ }^{20}$ In this equipment, the bottom part is movable and the top pin or ball is stationary. In the present study, the bottom movable flat surface was the borided steel and the upper fixed surface was the WC-Co ball with a diameter of $8 \mathrm{~mm}$. The wear experiments were carried out in a ball-disc arrangement under dry friction conditions at room temperature with an applied load of $10 \mathrm{~N}$ and with a sliding speed of $0.3 \mathrm{~m} / \mathrm{s}$ for a sliding distance of $1000 \mathrm{~m}$. Before and after each wear test, each sample and abrasion element was cleaned with alcohol. After the test, the wear volumes of the samples were quantified by multiplying the cross-sectional areas of the wear by the width of the wear track obtained from the Taylor-Hobson Rugosimeter Surtronic 25 device. The wear rate was calculated with the Equation (1):

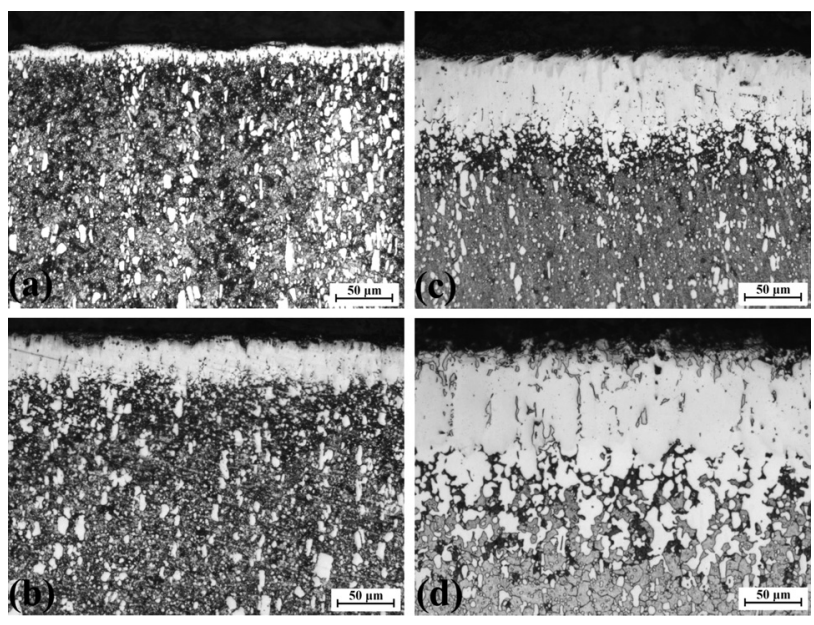

Figure 1: Cross-section of the borided AISI D6 steel: a) $1123 \mathrm{~K}-2 \mathrm{~h}$, b) $1123 \mathrm{~K}-8 \mathrm{~h}$, c) $1323 \mathrm{~K}-2 \mathrm{~h}$, d) $1323 \mathrm{~K}-8 \mathrm{~h}$

Slika 1: Presek boriranega jekla AISI D6: a) $1123 \mathrm{~K}-2 \mathrm{~h}$, b) $1123 \mathrm{~K}$ $-8 \mathrm{~h}, \mathrm{c}) 1323 \mathrm{~K}-2 \mathrm{~h}, \mathrm{~d}) 1323 \mathrm{~K}-8 \mathrm{~h}$

$$
W_{\mathrm{k}}=\frac{W_{\mathrm{v}}}{M \cdot S} \mathrm{~mm}^{3} / \mathrm{Nm}
$$

where $W_{\mathrm{k}}$ is the wear rate, $W_{\mathrm{v}}$ is the worn volume, $M$ is the applied load and $S$ is the sliding distance. Friction coefficients, depending on the sliding distance, were obtained through a friction-coefficient program. The surface profiles of the wear tracks on the samples and surface roughness were measured with a Taylor-Hobson Rugosimeter Surtronic 25. The worn surfaces were investigated by scanning electron microscopy (SEM), energy-dispersive X-ray spectroscopy (EDS) and with a Nanovea ST-400 non-contact optical profiler.

\section{RESULTS AND DISCUSSION}

\subsection{Characterization of boride coatings}

The cross-sections of the optical micrographs of the borided AISI D6 steel at $1123 \mathrm{~K}$ and $1323 \mathrm{~K}$ for $2 \mathrm{~h}$ and $8 \mathrm{~h}$ are shown in Figure 1. It is clear that the borides formed on the AISI D6 substrate have a saw-tooth morphology. It was found that the coating/matrix interface and matrix could be easily distinguished and the boride layer had a columnar structure. Depending on the chemical composition of the substrates, boriding time and temperature the boride layer thickness on the surface of the AISI D6 steel ranged from $13.54 \mu \mathrm{m}$ and $164.42 \mu \mathrm{m}$ in Figure 2.

Figure 3 gives the XRD pattern obtained from the surface of borided AISI D6 steel at $1123 \mathrm{~K}$ and $1323 \mathrm{~K}$ for treatment times of $2 \mathrm{~h}$ and $8 \mathrm{~h}$. The XRD patterns show that the boride layer consists of borides such as SB and $\mathrm{S}_{2} \mathrm{~B}$ ( $\mathrm{S}=\mathrm{Metal} ; \mathrm{Fe}, \mathrm{Cr}$ ). The XRD results show that the boride layers formed on the AISI D6 steel contained the $\mathrm{FeB}, \mathrm{Fe}_{2} \mathrm{~B}, \mathrm{CrB}$ and $\mathrm{Cr}_{2} \mathrm{~B}$ phases in Figure 3 .

Micro-hardness measurements were carried out from the surface to the interior along a line in order to see the

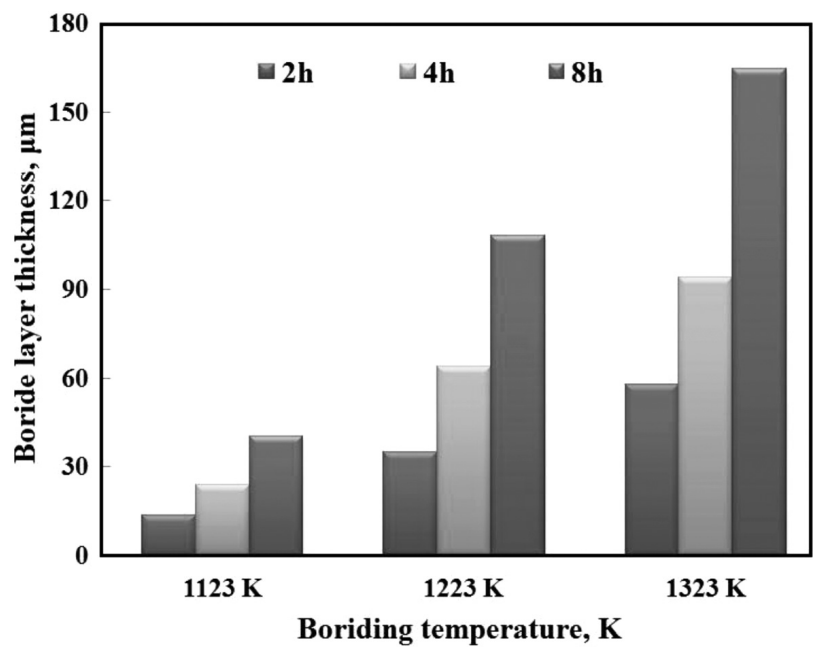

Figure 2: Thickness values of boride layers with respect to boriding time and temperatures

Slika 2: Debelina borirane plasti glede na čas in temperaturo boriranja 


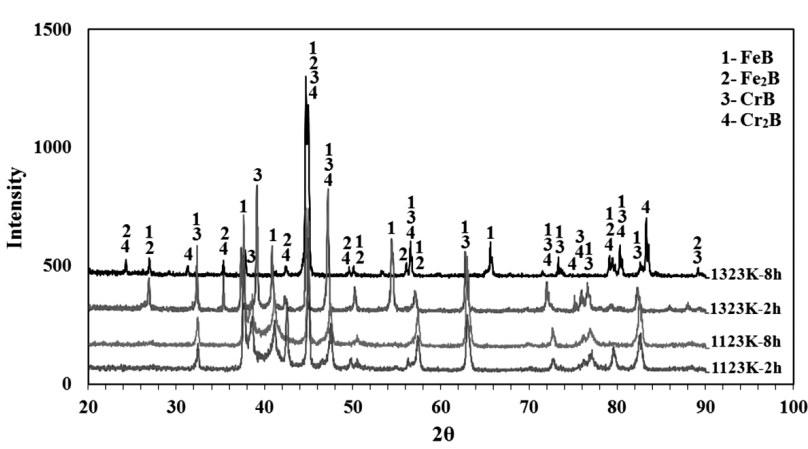

Figure 3: X-ray diffraction patterns of borided AISI D6 steel Slika 3: Rentgenska difrakcija boriranega jekla AISI D6

variations in the boride layer hardness, transition zone and matrix. The micro-hardness of the boride layers was measured at 10 different locations at the same distance from the surface and the average value was taken as the hardness. Micro-hardness measurements were carried out on the cross-sections from the surface to the interior along a line (Figure 4). The hardness of the boride layer formed on the AISI D6 steel varied between $1672 \mathrm{HV}_{0.05}$ and $2118 \mathrm{HV}_{0.05}$. On the other hand, the Vickers hardness values were $584 \mathrm{HV}_{0.5}$, for the untreated AISI D6 steel. When the hardness of the boride layer is compared with the matrix, the boride layer hardness is approximately four times greater than that of the matrix.

\subsection{Friction and wear behavior}

Figure 5 shows the surface roughness values of the borided and unborided AISI D6 steel. For the AISI D6 steel it was observed that the surface-roughness values increased with the boriding treatment. C. $\mathrm{Li}^{21}$ and $\mathrm{S}$. Sahin $^{22}$ solid borided different steels and reported that surface-roughness values increased with an increase in the boriding temperature. On the other hand, the friction coefficients of the unborided and borided AISI D6 steel varied from 0.39 to 0.62 , as can be seen in Table 1. With the boriding treatment, a slight reduction was observed in the friction coefficients of the borided steels.

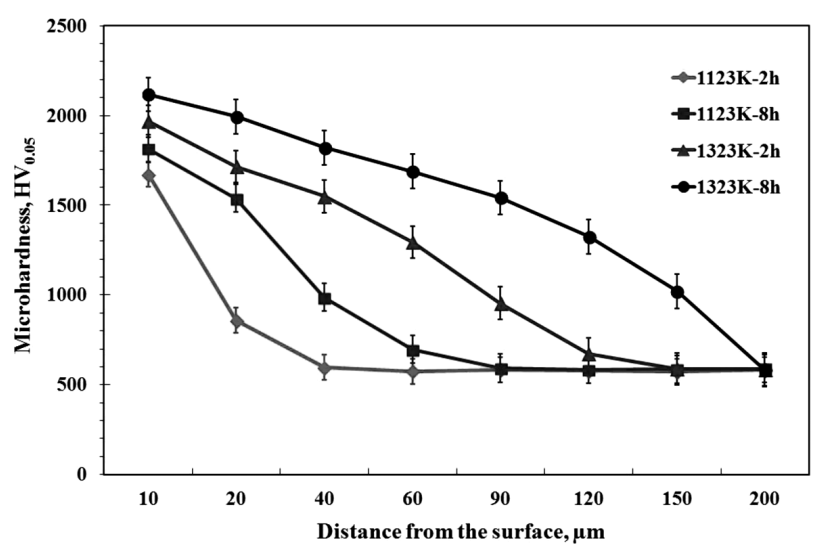

Figure 4: Variation of hardness depth in the borided AISI D6 steel Slika 4: Spreminjanje trdote po globini boriranega jekla AISI D6

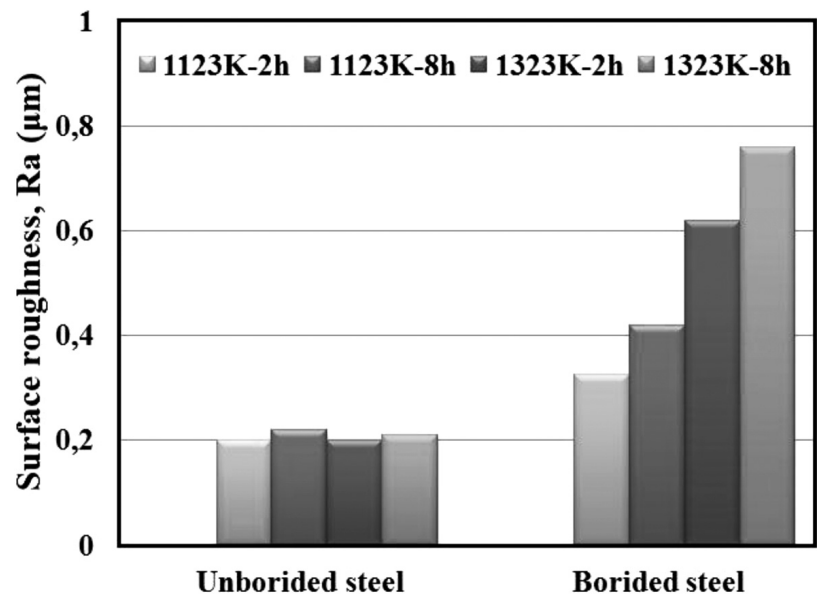

Figure 5: Surface-roughness values of the unborided and borided AISI D6 steel

Slika 5: Vrednosti površinske hrapavosti neboriranega in boriranega jekla AISI D6

Table 1: Friction coefficients of the unborided and borided AISI D6 steel

Tabela 1: Koeficient trenja neboriranega in boriranega jekla AISI D6

\begin{tabular}{|c|c|c|c|c|}
\hline \multirow{3}{*}{ Unborided } & \multicolumn{4}{|c|}{ Borided } \\
\cline { 2 - 5 } & $\begin{array}{c}1123 \mathrm{~K}- \\
2 \mathrm{~h}\end{array}$ & $\begin{array}{c}1123 \mathrm{~K}- \\
8 \mathrm{~h}\end{array}$ & $\begin{array}{c}1323 \mathrm{~K}- \\
2 \mathrm{~h}\end{array}$ & $\begin{array}{c}1323 \mathrm{~K}- \\
8 \mathrm{~h}\end{array}$ \\
\hline 0.62 & 0.39 & 0.47 & 0.51 & 0.58 \\
\hline
\end{tabular}

Figure 6 shows the wear rate of the unborided and borided AISI D6 steel. Reductions in the wear rates of the borided steels were observed according to the unborided steels. Due to the toughness of the $\mathrm{FeB}, \mathrm{Fe}_{2} \mathrm{~B}$, $\mathrm{CrB}$ and $\mathrm{Cr}_{2} \mathrm{~B}$ phases, the steel showed more resistance to wear. While the highest wear rate is observed for the unborided AISI D6 steel $\left(81.2 \times 10^{-6} \mathrm{~mm}^{3} / \mathrm{Nm}\right)$, the lowest wear rate was found for the borided AISI D6 steel at $1323 \mathrm{~K}$ for $8 \mathrm{~h}\left(1.28 \times 10^{-6} \mathrm{~mm}^{3} / \mathrm{Nm}\right)$. The wear test results indicated that the wear resistance of the borided steels increased considerably with the boriding treatment

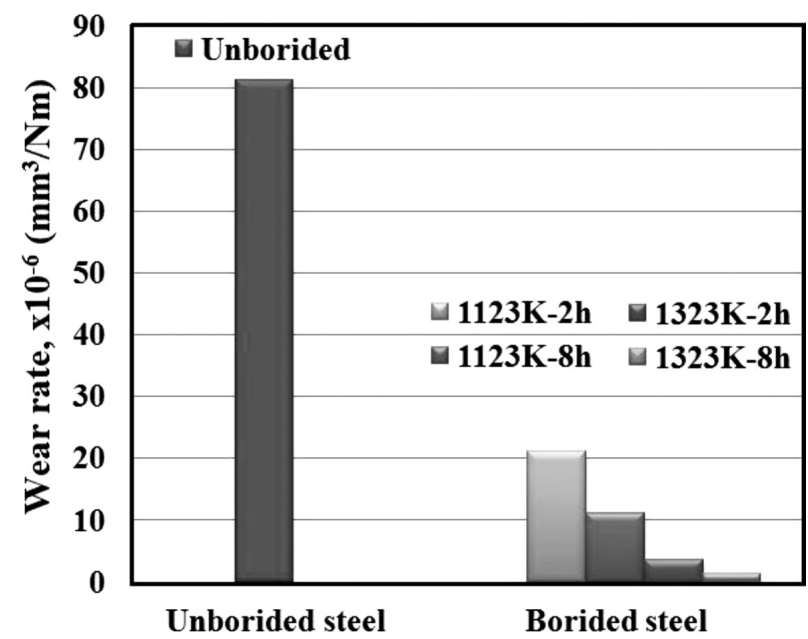

Figure 6: Wear rate of unborided and borided AISI D6 steel Slika 6: Hitrost obrabe neboriranega in boriranega AISI D6 jekla 
I. GUNES, S. KANAT: INVESTIGATION OF WEAR BEHAVIOR OF BORIDED AISI D6 STEEL
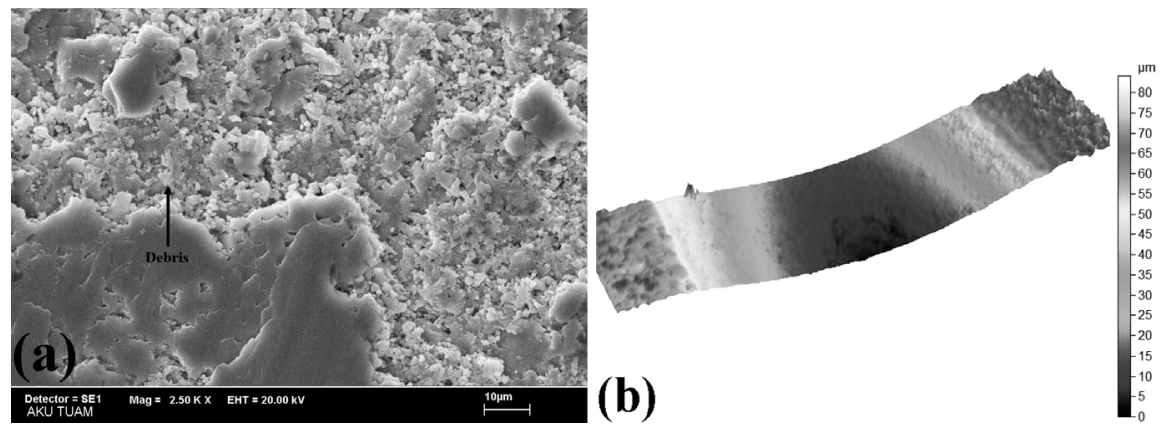

Figure 7: SEM micrograph and cross-sectional surface of the worn-out surfaces of the unborided AISI D6 steel: a) unborided, b) cross-sectional surface $(\mathrm{CS})$

Slika 7: SEM posnetek površine in presek obrabljene površine neboriranega jekla AISI D6: a) neborirano, b) presek obrabljene površine (CS)
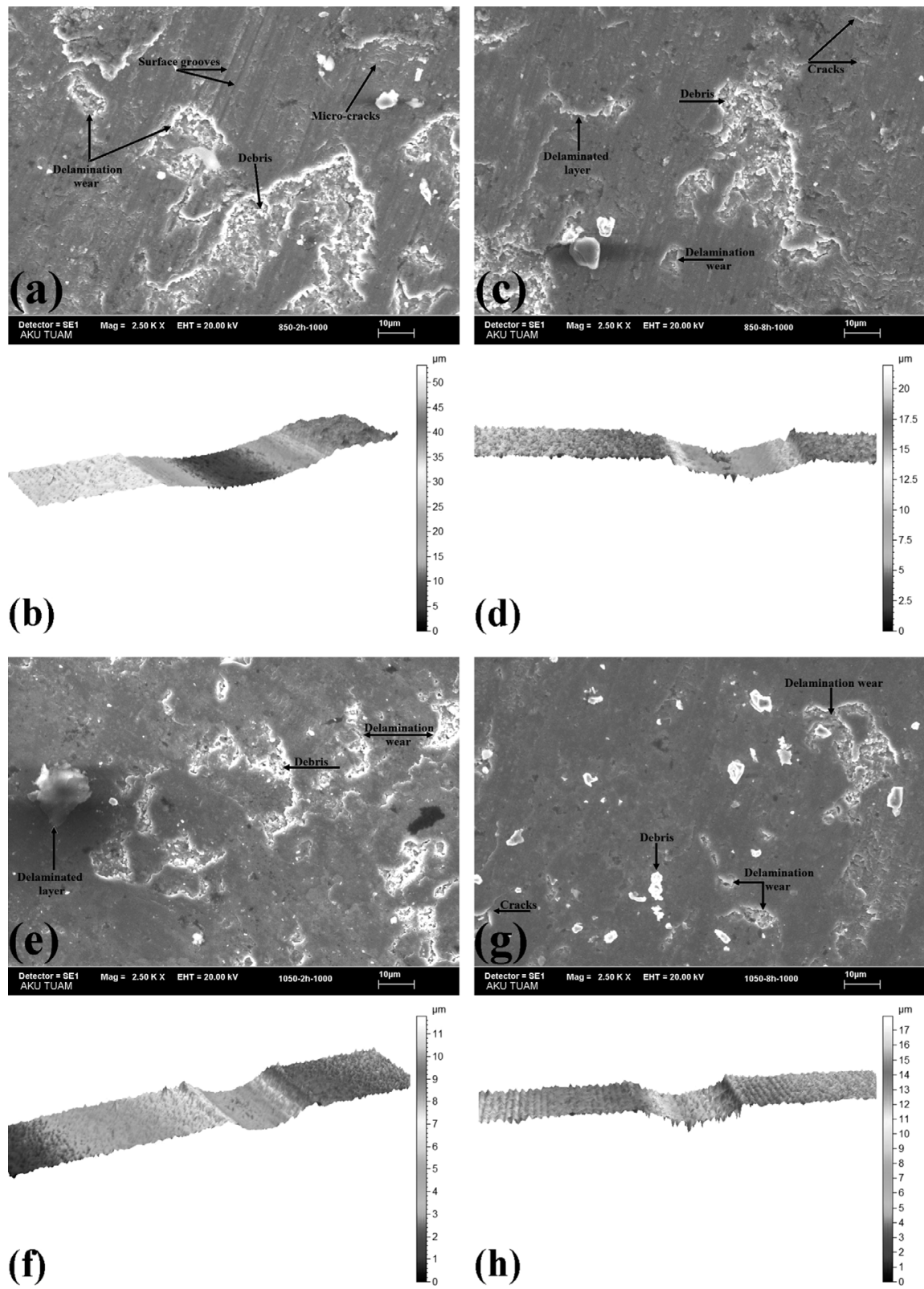

Figure 8: SEM micrographs and cross-sectional surface of the worn-out surfaces of the borided AISI D6 steel: a) $1123 \mathrm{~K}-2 \mathrm{~h}, \mathrm{~b}) 1123 \mathrm{~K}-2 \mathrm{~h}$ CS, c) $1123 \mathrm{~K}-8 \mathrm{~h}$, d) $1123 \mathrm{~K}-8 \mathrm{~h} \mathrm{CS}$, e) $1323 \mathrm{~K}-2 \mathrm{~h}$, f) $1323 \mathrm{~K}-2 \mathrm{~h}$ CS, g) $1323 \mathrm{~K}-8 \mathrm{~h}, \mathrm{~h}) 1323 \mathrm{~K}-8 \mathrm{~h} \mathrm{CS}$

Slika 8: SEM posnetek površine in presek obrabljene površine na boriranem jeklu AISI D6: a) $1123 \mathrm{~K}-2 \mathrm{~h}$, b) $1123 \mathrm{~K}-2 \mathrm{~h}$ CS, c) $1123 \mathrm{~K}-8 \mathrm{~h}$, d) $1123 \mathrm{~K}-8 \mathrm{~h} \mathrm{CS}$, e) $1323 \mathrm{~K}-2 \mathrm{~h}, \mathrm{f}) 1323 \mathrm{~K}-2 \mathrm{~h} \mathrm{CS}$, g) $1323 \mathrm{~K}-8 \mathrm{~h}, \mathrm{~h}) 1323 \mathrm{~K}-8 \mathrm{~h} \mathrm{CS}$ 
and time. It is well known that the hardness of the boride layer plays an important role in the improvement of wear resistance. As shown in Figures 4 and 6, the relationship between the surface microhardness and the wear resistance of the borided samples also confirms that the wear resistance was improved with the increasing hardness. This is in agreement with the reports of previous studies. ${ }^{17-22}$ Comparing the wear rate of the borided steel with the unborided steel, the wear rate of the borided steels is approximately four times lower. The wear rate of the unborided sample was $81.2 \times 10^{-6} \mathrm{~mm}^{3} / \mathrm{Nm}$; however, this value dropped to $1.28 \times 10^{-6} \mathrm{~mm}^{3} / \mathrm{Nm}(1323 \mathrm{~K}$ $-8 \mathrm{~h}$ ) as a result of the boriding process.

The SEM micrographs of the worn surfaces of the unborided and borided AISI D6 steel are illustrated in Figures 7 and 8. Figure 7a shows the SEM micrographs of the wear surfaces and Figure $\mathbf{7 b}$ shows the cross-sectional surface (CS) of the wear mark obtained from the wear region of the unborided AISI D6 steel. In Figure $7 \mathbf{a}$, the worn surface of the unborided steel was rougher and coarser wear-debris particles were present. The wear region of the borided steel, debris, delamination wear, surface grooves and cracks on the surface can be seen (Figure 8). There were micro-cracks, abrasive particles and small holes on the worn surface of the boride coatings. In the wear region of the borided AISI D6 steel there were cavities probably formed as a result of layer fatigue (Figure 8) and the cracks concluded in delaminating wear. Figure 8 shows the wear surfaces, and the cross-sectional surface (CS) of the wear mark obtained from the wear region by analyzing multiple profilometry surface line scans using a Nanovea ST-400 non-contact optical profiler. It was observed that the depth and the width of the wear trace on the surfaces of the samples decreased with an increase in the boriding temperature and time (Figures $\mathbf{7 b}, \mathbf{7 d}, \mathbf{7 f}$ and $\mathbf{7 h}$ ). When the SEM image of the worn surfaces of the unborided sample is examined, it can be seen that the wear marks in Figure $7 \mathbf{a}$ are larger and deeper.

\section{CONCLUSIONS}

In this study the wear behavior and some of the mechanical properties of borides on the surface of borided AISI D6 steel were investigated. Some of the conclusions are as follows.

- The boride layer thickness on the surface of the AISI D6 steel was obtained, depending on the chemical composition of the substrates, 13.54-164.42 $\mu \mathrm{m}$.

- The multiphase boride coatings that were thermochemically grown on the AISI D6 steel were made up of the $\mathrm{FeB}, \mathrm{Fe}_{2} \mathrm{~B}, \mathrm{CrB}$ and $\mathrm{Cr}_{2} \mathrm{~B}$ phases.

- The surface hardness of the borided steel was in the range 1672-2118 $\mathrm{HV}_{0.05}$, while for the untreated steel substrate it was $584 \mathrm{HV}_{0.05}$.

- The coefficient-of-friction values for the borided samples (between 0.39 and 0.58 ) were lower than the coefficient-of-friction values (0.62) for the unborided steel sample.

- The lowest wear rate was obtained for the steel borided at $1323 \mathrm{~K}$ for 8 hours, while the highest wear rate was obtained for the unborided steel.

- The wear rate of the borided steel was found to be approximately four times lower than the wear rate of the unborided steel.

\section{Acknowledgement}

The authors are grateful to the Scientific Research Project (14.FEN.BİL.49) Council of Afyon Kocatepe University. This article was based on Salih Kanat's master's thesis.

\section{REFERENCES}

${ }^{1}$ A. G. von Matuschka, Boronizing, Heyden and Son Inc., Philadelphia, USA 1980, 11

${ }^{2}$ A. K. Sinha, Boriding (Boronizing), ASM Handbook, Vol. 4, J. Heat Treating, ASM International, OH, USA 1991, 437-447

${ }^{3}$ M. Keddam, S. M. Chentouf, A diffusion model for describing the bilayer growth $(\mathrm{FeB} / \mathrm{Fe} 2 \mathrm{~B})$ during the iron powder-pack boriding, Applied Surface Science, 252 (2005), 393-399, doi:10.1016/ j.apsusc. 2005.01.016

${ }^{4}$ I. Gunes, Tribological behavior and characterization of borided cold-work tool steel, Mater. Tehnol., 48 (2014), 765-769

${ }^{5}$ I. Gunes, Kinetics of borided gear steels, Sadhana, 38 (2013), 527-541, doi:10.1007/s12046-013-0138-0

${ }^{6}$ M. Hudakova, M. Kusy, V. Sedlicka, P. Grgac, Analysis of the boronized layer on K 190 PM tool steel, Mater. Tehnol., 41 (2007) 2, 81-84

${ }^{7}$ M. Keddam, M. Kulka, N. Makuch, A. Pertek, L. Maldzinski, A kinetic model for estimating the boron activation energies in the $\mathrm{FeB}$ and $\mathrm{Fe}_{2} \mathrm{~B}$ layers during the gas-boriding of Armco iron: Effect of boride incubation times, Applied Surface Science, 298 (2014), 155-163, doi:10.1016/j.apsusc.2014.01.151

${ }^{8}$ I. Gunes, S. Taktak, Surface characterization of pack and plasma paste boronized of $21 \mathrm{NiCrMo} 2$ steel, Journal of the Faculty of Engineering and Architecture of Gazi University, 27 (2012), 99-108

${ }^{9}$ G. Kartal, O. Kahvecioglu, S. Timur, Investigating the morphology and corrosion behavior of electrochemically borided steel, Surface Coatings Technology, 200 (2006), 3590-3593, doi:10.1016/ j.surfcoat. 2005.02.210

${ }^{10}$ R. Matsumoto, K. Osakada, Development of warm forging method for magnesium alloy, Materials Transactions, 45 (2004) 9, 2838-2844, doi:10.2320/matertrans.45.2838

${ }^{11}$ I. Gunes, M. Erdogan, A. G. Çelik, Corrosion behavior and characterization of plasma nitrided and borided AISI M2 steel, Materials Research, 17 (2014) 3, 612-618, doi:10.1590/S151614392014005000061

${ }^{12}$ W. Muhammad, Boriding of high carbon high chromium cold work tool steel, Materials Science and Engineering, 60 (2014), 1-6, doi:10.1088/1757-899X/60/1/012062

${ }^{13}$ I. Ozbek, S. Sen, M. Ipek, C. Bindal, S. Zeytin, H. A. Ucisik, A mechanical aspect of borides formed on the AISI 440C stainless-steel, Vacum, 73 (2004), 643-648, doi:10.1016/j.vacuum.2003.12.083

${ }^{14}$ M. Erdogan, I. Gunes, Corrosion Behavior and Microstructure of Borided Tool Steel, Revista Matéria, 20 (2015), 523-529, doi:10.1590/ S1517-707620150002.0052

${ }^{15}$ C. Bindal, A. H. Ucisik, Characterization of boriding of $0.3 \% \mathrm{C}$, $0.02 \%$ P plain carbon steel, Vacuum, 82 (2008), 90-94, doi:10.1016/ j.vacuum.2007.04.039 


\section{GUNES, S. KANAT: INVESTIGATION OF WEAR BEHAVIOR OF BORIDED AISI D6 STEEL}

${ }^{16}$ I. Gunes, Tribological properties and characterisation of plasma paste borided AISI 5120 steel, Journal of the Balkan Tribological Association, 20 (2014), 351-361

${ }^{17}$ M. Tabur, M. Izciler, F. Gul, I. Karacan, Abrasive wear behavior of boronized AISI 8620 steel, Wear, 266 (2009), 1106-1112, doi:10.1016/j.wear.2009.03.006

${ }^{18}$ C. Martini, G. Palombarini, G. Poli, D. Prandstraller, Sliding and abrasive wear behaviour of boride coatings, Wear, 256 (2004), 608-613, doi:10.1016/j.wear.2003.10.003

${ }^{19}$ I. Gunes, Investigation of tribological properties and characterization of borided AISI 420 and AISI 5120 steels, Transactions of the Indian Institute of Metals, 67 (2014), 359-365, doi:10.1007/s12666-0130356-5.
${ }^{20}$ S. Taktak, M. S. Baspinar, Wear and friction behaviour of alumina/ mullite composite bysol-gel infiltration technique, Materials and Design, 26 (2005), 459-464, doi:10.1016/j.matdes.2004.07.012

${ }^{21}$ C. Li, B. Shen, G. Li, C. Yang, Effect of boronizing temperature and time on microstructure and abrasion wear resistance of Cr12Mn2V2 high chromium cast iron, Surface and Coatings Technology, 202 (2008), 5882-5886, doi:10.1016/j.surfcoat.2008.06.170

${ }^{22} \mathrm{~S}$. Sahin, Effects of boronizing process on the surface roughness and dimensions of AISI 1020, AISI 1040 and AISI 2714, Journal of Mater. Process. Tech., 209 (2009), 1736-1741, doi:10.1016/ j.jmatprotec.2008.04.040 